\title{
Bio-based additives for thermoplastics
}

\author{
Marco Aurelio De Paoli* (D) and Walter Ruggeri Waldman² \\ 1 Laboratório de Processamento de Polímeros, Instituto de Química, Universidade Estadual de Campinas \\ - UNICAMP, Campinas, SP, Brasil \\ ${ }^{2}$ Centro de Ciências e Tecnologias para Sustentabilidade, Universidade Federal de São Carlos - UFSCar, \\ Campus de Sorocaba, Sorocaba, SP, Brasil \\ *madpaoli@unicamp.br
}

\begin{abstract}
Presently, there are significant research efforts being undertaken to produce bio-based chemicals in a cost-effective way. The polymer chemists and engineers are no exception to this. Additives for polymers correspond to a large section of the plastics market and bio-based products can substitute many of them. The scientific literature has a large number of publications focusing on the preparation and testing of bio-based polymer additives; however, the small number of products that reach the market, which are bio-based, does not reflect this. In terms of the global market, the environmentally friendly appeal of bio-based additives alone is not sufficient; the bio-based product must have similar or better performance than the oil-based and be comparable or lower in cost than the existing products. In this review, we focus on bio-based polymer additives that have already reached the market or have a real possibility of reaching the market in a cost-effective way.
\end{abstract}

Keywords: thermoplastics, bio-based, additives, renewable, environmentally friendly.

How to cite: De Paoli, M. A., \& Waldman, W. R. (2019). Bio-based additives for thermoplastics. Polimeros: Ciência e Tecnologia, 29(2), e2019030. https://doi.org/10.1590/0104-1428.06318

\section{Introduction}

In the early days of polymer production, the majority of raw materials used by the industry were obtained from renewable resources or mining. With the development and growth of the petrochemical industry, raw materials derived from commodities obtained from petrol became dominant. Now, almost two centuries later, this trend is reversing. Environmental concern and cost are the main causes of this reversion and bio-based polymers and additives are reaching the market. However, the mere fact that a raw material is bio-based (or renewable) does not enable its use by industry. Large-scale production, reproducible properties, and a competitive cost in relation to its routinely used oil-based counterpart are important variables to take into account. Additionally, being a bio-based (or renewable) material does not means that it is non-toxic (snake venom is natural and renewable!) or non-harmful to the environment.

There is a very large number of publications related to bio-based additives for polymers; however, as highlighted above, there is a long way from the lab bench to the polymer market, and cost effectiveness is the largest barrier to be crossed. There are reviews discussing academic works on different kinds of bio-based polymer additives, but this review will focus on the bio-based additives that are already in the market or may reach it in a short time scale.
Polymers have additives added to adjust their final properties and performance for a particular application and/or to facilitate their processing. Additives represent a small percentage by weight of the formulation, but they have a strong impact on the final cost of a plastic product. Exceptions are plasticizers, which have a low cost and may be present in poly(vinyl chloride), PVC, at concentrations as high as $50 \%$ in weight (wt. \%).

Reinforcing agents are one class of additives used specifically to modify the mechanical properties of a thermoplastic. Improvement of the tensile and flexural strengths are the aims in using these additives. Presently, the most commonly used reinforcing agents are glass fibers, talc, carbon fibers and nanosized chemically modified clays. However, there is a growing trend for substituting these for vegetal fibers in some specific applications.

In this review, the term bio-based is used for a chemical species " $[\ldots]$ composed or derived in whole or in part of biological products issued from biomass (including plant,

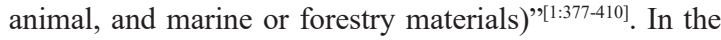
case of polymer additives, it is also important to consider the production scale, as well as the existing and/or potential market. A bio-based additive may fit into the above-mentioned definition, but it also has to be industrially produced, distributed, and sold, or have the potential to reach the market in a reasonable timescale. In general, the data available on bio-based additives is scarce and patents protect detailed 
chemical information of commercial products. An interesting remark regarding the current status of bio-based additives is that during the review process of the manuscript, after the requests from the reviewers, we checked the links of the products we have scanned for the first submission, and some products were no longer available two months later. This is a hint of how much this market is volatile and has yet to mature to achieve a consolidated status.

To the best of our knowledge, the bio-based additives used nowadays, produced from renewable resources, are plasticizers, colorants, biocides/antimicrobial agents, antistatic agents, antifogging agents, lubricants, flame retardants/smoke suppressants, and stabilizers (antioxidants, photostabilizers, and acid scavengers).

In this review, we focus on bio-based additives and reinforcement agents used for thermoplastics and commercially available or with potential to enter the market.

\subsection{Plasticizers}

These additives are used to improve the flexibility of thermoplastics by reducing the intermolecular interactions. Therefore, they lower the glass transition and the melting temperatures of the polymer. Thermoplastics use plasticizers extensively, reaching concentrations as high as $50 \mathrm{wt}$ \%. The plasticizers market, including bio-based ones, will be worth US\$ 19,367 million dollars by $2019^{[2]}$. The global bio plasticizers market was valued at approximately USD 836 million in 2017 and is expected to generate revenue of USD 1,657 million by $2024^{[3]}$.

Early phthalate-based plasticizers corresponded to $85 \%$ of the total plasticizers market. In the last decade, due to toxicity concerns, their application was restricted and terephthalate and bio-based plasticizers appeared on the market.

The raw materials used for production of bio-based plasticizers are soybean oil, linseed oil, palm oil, sunflower oil, and castor oil. These polyunsaturated vegetable oils have high numbers of carbon-carbon double bonds available for epoxidation and are used as precursors to epoxidized oil products ${ }^{[4]}$. Usually, a peroxide or a peroxyacid is used to add an oxygen atom and convert the $-\mathrm{C}=\mathrm{C}-$ bond to an epoxide group ${ }^{[5]}$. The epoxidized vegetable oils act as plasticizers, e.g. reducing the interactions between the electropositive and electronegative groups of PVC. The carbonyls of the ester groups interact with the electropositive hydrogen atoms and the hydrocarbon tails interact with the electronegative chlorine atoms. Additionally, the epoxide groups are more reactive than carbon-carbon double bonds, thus providing the additional advantage of acting as a good acid scavenger ${ }^{[6]}$. Thus, for PVC, they have the additional characteristic of acting as a stabilizer. Recent studies have shown that epoxidized sunflower oil is also a good plasticizer and stabilizer for PVC, pure or combined with other plasticizers ${ }^{[7]}$. An additional advantage for the use of epoxidized oils as additives in polymers is that, they can act as stabilizers where the mechanism of degradation comprises evolution of acid substances, like $\mathrm{HCl}$, the main by-product of the PVC degradation.

The lower cost of soybean oil, in comparison to other vegetable oils, makes epoxidized soybean oil the most commonly used bio-based plasticizer in the food packaging market. Overall, the global bio-plasticizers market finds applications in food packaging, medical devices, consumer goods, toys, wire/cables, and the construction and automotive industries. For the automotive industry, epoxidized vegetable oils have the additional advantage of producing less VOC (volatile organic compounds) in comparison to phthalate-based plasticizers.

The cost of bio-based plasticizers, compared with phthalate-based ones, is a key challenge faced by the bio-based plasticizers market. The present number of commercial bio-based plasticizer products on the market are epoxidized soybean oil (26), citrates (13), sebacates (9), epoxidized linseed oil (6), and adipates $(5)^{[8]}$.

Bio-based plasticizers are widely used as additives in PVC resins for the production of cables, flooring, wire jacketing, food containers, automobile parts, etc. The use of bio-based plasticizers for wire applications can enable manufacturers to reduce carbon gas emissions by up to $40 \%$. These bio-plasticizers, when used for cable manufacturing, offer various advantages in terms of electrical and temperature performance compared with traditional plasticizers ${ }^{[9]}$. Table 1 exemplifies a group of bio-based plasticizers currently in the market.

In the near future, one can envisage a tendency to ban petrol-based plasticizers and use exclusively bio-based plasticizers.

Table 1. Examples of bio-based plasticizers currently in the market.

\begin{tabular}{|c|c|c|c|c|}
\hline Trade name & Composition & Manufacturer & Comments & Refs. \\
\hline Plasthall $^{\circledR}$ & $\begin{array}{l}\text { Renewable esters with long } \\
\text { carbon chain. }\end{array}$ & Hallstar (USA) & $\begin{array}{l}\text { According to the producer, the esters are polymeric, not only } \\
\text { the molecules. A low leaching is expected. }\end{array}$ & {$[10]$} \\
\hline Vikoflex $^{\circledR}$ & Epoxidized vegetable oils & Arkema (France) & $\begin{array}{l}\text { Main market aspect is the reliability on the oxirane (epoxide } \\
\text { ring) content. }\end{array}$ & [11] \\
\hline Jayflex ${ }^{\mathrm{TM}}$ & Adipate & Exxon Mobil (USA) & $\begin{array}{l}\text { Used for low-temperature purposes and typically not alone, } \\
\text { but in blends with phthalates, not replacing, but reducing the } \\
\text { use of phthalates. }\end{array}$ & [12] \\
\hline Morflex $^{\circledR}$ & Dibutyl Sebacate & Vertellus (USA) & $\begin{array}{l}\text { Used for low-temperature applications, like packaging films } \\
\text { for refrigerated food. }\end{array}$ & {$[13]$} \\
\hline Reflex $^{\mathrm{TM}}$ & Soybean oil derivatives & PolyOne (USA) & - & {$[14]$} \\
\hline
\end{tabular}




\subsection{Colorants}

Humankind has used colorants since the first cavemen painted the walls of their caverns. The methods for production of colorants and lightfast colorants was, for many centuries, a valuable secret. Iron blue, for example, is reported as the first colorant produced on the industrial scale after $1724^{[15]}$. The English and German chemical industries were born and flourished in the $19^{\text {th }}$ century, producing dyes and pigments. Colorants based on lead, cadmium, and chromium were dominant for industrial applications until the second half of the $20^{\text {th }}$ century. With the birth of the environmental movement in the 1970s and the growing awareness of the environmental impacts of human activities, inorganic dyes appeared on the environmentalists' radar, and their toxic effects led to movements banning them from the 1980 s onwards ${ }^{[16]}$.

Routinely, the word pigment is used for color agents; however, the term colorant used here is more adequate as it comprises both dyes and pigments. Colorants for thermoplastics are classified in two categories: pigments when the colorant does not dissolve in the polymeric matrix, and dyes - when the colorant dissolves into solution with the polymers. Pigments can be inorganic, mostly metal oxides and sulfides, or organic, such as phthalocyanines or carbon black. Dyes are mostly organic, and the main classes are the anthraquinones and perinones. Although some anthraquinones are found in nature, their industrial production is based on the oxidation of anthracene. Organic colorants derived from anthraquinone, like Alizarin ${ }^{[17]}$ and Carminic acid, have in common a thermally stable polyaromatic and conjugated chemical structure, Figure 1, which can resist thermal stress during processing. Bio-based colorants are not stable under this kind of stress. Because of this, bio-based colorants like indigoids, carotenoids, quininoids, among others, mostly find application in the field of textile fibers, which are less thermally stressed during their processing. We will not discuss this matter further as the focus of this review is thermoplastics, but we refer the reader to a comprehensive review on this subject ${ }^{[18]}$.

Despite the efforts to study these alternative additives ${ }^{[19]}$, we did find only one industrially produced bio-based colorant

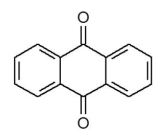

Anthraquinone
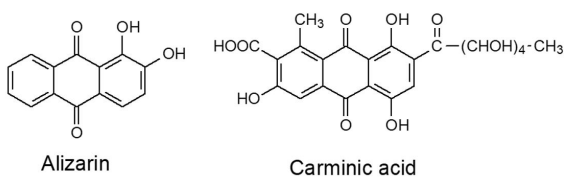

Figure 1. Chemical representations of anthraquinone (top) and two of the anthraquinone-based colorants, Alizarin (bottom left) and Carminic acid (bottom right).
(Table 2) for use in thermoplastics. The manufacturer did not disclose the bio-based ingredient; however, it did provide the certification for biodegradability and compostability.

\subsection{Biocides/antimicrobial agents}

Historically, humankind has used substances to prevent bacterial infection for millennia, even though the existence of microorganisms, such as bacteria and fungi was not known. One example is the biocidal or antimicrobial action of the essential oils present in most spices, including pepper and oregano $^{[21]}$. This explains why poor sanitary conditions are often associated with spicy foods. Additionally, a large number of essential oils tested positive as active antimicrobial agents for food packaging ${ }^{[22]}$.

The term antimicrobial, used here, is more general and adequate than biocide. Biocide means "any chemical substance that destroys life" ( $b i o=$ life and cide = kill, destroy), whereas antimicrobial limits its action to microorganisms. This class of additives, antimicrobial agents, comprises algaecides, antifouling agents, fungicides, bactericides, and bacteriostats. The main areas of application of these additives are textiles, food packaging, and medical appliances. Marine applications are the main use for antifouling agents and these additives will not be discussed here.

Persistence is the main technical issue with the use of antimicrobial agents in polymers and, in general, inorganic compounds or metallic silver are used. However, silver or nanosized silver are harmful to the environment after lixiviation from the polymer. Other alternatives are thiazole derivatives and halogenated compounds. There is little mention in the literature of bio-based commercial products of this class.

Chitosan, a hydrophilic polysaccharide derived from chitin, is the main constituent of the outer skeleton of insects and crustaceans, such as shrimp, crab, and lobster ${ }^{[23]}$. It shows a broad antimicrobial spectrum to which gram-negative, gram-positive bacteria, and fungi are highly susceptible. In the case of fungi, it shows fungistatic properties ${ }^{[24]}$. There are many studies about the minimum inhibitory concentration (MIC) for chitin, chitosan, their derivatives, or combinations thereof, with different results for different microorganisms. MIC is the lowest concentration of an antimicrobial that will inhibit the visible growth of a microorganism after overnight incubation. A summary of this property for chitosan is available in the literature ${ }^{[25]}$. To have the antimicrobial material available for microorganisms, the chitosan should be at the outer layer of the polymer matrix and migration to the bulk should be avoided. Chitosan can be used in polymer blends prepared by reactive extrusion or as an antimicrobial coating in film packaging ${ }^{[26]}$. Despite the availability of this bio-based raw material and knowledge

Table 2. Example of bio-based colorant currently in the market.

\begin{tabular}{cccc}
\hline Trade name & \multicolumn{1}{c}{ Composition } & Manufacturer & Comments \\
\hline OnColor & $\begin{array}{l}\mathrm{TiO}_{2} \text { and other allegedly bio-based } \\
\text { and compostable compounds. }\end{array}$ & PolyOne (USA) & $\begin{array}{l}\text { Despite the comments on the website, the MSDS sheets only describes } \\
\mathrm{TiO}_{2} \text {, explaining that there are no additional ingredients that are } \\
\text { classified as hazardous for health or environment }\end{array}$ \\
\hline
\end{tabular}


of its antimicrobial activity, for thermoplastics there is no commercial product on the market based on this material.

Presently, there are a few commercial bio-based antimicrobials ${ }^{[27]}$, shown below:

Gaia $^{\circledR}$ AB 504 Antimicrobial is an organic concentrate produced from citrus extracts that controls or retards the growth of bacteria, fungus, and algae in plastic molded parts.

Gaia $^{\circledR}$ Byoprotec is a proprietary blend of various organic products consisting of citric acid, citrus extract, and a blend of unique quaternary proprietary ammonium chloride salts.

Propolis offers antiseptic, antibiotic, antifungal, and even antiviral properties. Propolis starts as a sticky resinous sap, which seeps from the buds of certain trees and oozes from the bark of others. It tested positive for biocide action in natural rubber vulcanizates ${ }^{[28]}$.

The potential future markets for bio-based antimicrobian additives are in biodegradable or edible food packaging or films for food packaging and medical appliances. Table 3 exemplifies bio-based antimicrobian additives (commercially named biocides), currently in the market.

\subsection{Antistatic agents and antifogging agents}

Conventional polymers are insulators and static electricity can occur on the surface of polymer films. Antistatic agents are additives included in their formulation to generate electric conductivity on the surface of the polymer films and dissipate the static electricity.

Antistatic agents also act as antislipping agents because prevention of static electricity also prevents slipping of the films. Electric conductivity in polymeric devices is also necessary in components in different industrial machineries, because these machines must be grounded to avoid electric discharges, which may cause fire or explosions. The same property is necessary for the soles of shoes used by workers in environments with organic flammable vapors and in packaging electronic devices. Conducting fillers are present in the formulation of these polymeric devices to provide bulk electric conductivity and avoid accidents.

In the case of films, the antistatic agent acts on the surface of the polymer. Hydrophilic end groups in the additive long-chain molecule aid its diffusion into the hydrophobic media of polymers. After diffusion to the surface, the hydrophilic end of the molecule interacts with water molecules in the atmosphere, creating a dissipative surface on the film. A bio-based additive used for this purpose is Erucamide, cis-13-docosenoamide, derived from cis-13-docosenoic acid, Figure 2, obtained from canola and rapeseed oils ${ }^{[30]}$. Erucamide also can act as lubricant and slip agent, due to its low molar mass chain, which has an effect on free volume, fostering the movement of the polymer chains.

Glycerol monostearate is also used as an antistatic and antislipping agent in polymer films. It is produced by the esterification of stearic acid (octadecanoic acid) with glycerol. Stearic acid and glycerol are bio-based raw materials. Stearic acid is obtained from fats and oils by the saponification of their triglycerides by using hot water (about $100{ }^{\circ} \mathrm{C}$ ). The resulting mixture is distilled to separate the pure form of the acid $^{[22]}$. Glycerol is also obtained from vegetal species and is the major byproduct from the production of biodiesel.

Conductive carbon black is the most commonly used conductive filler, which imparts bulk electric conductivity to polymers. Depending on the source of carbon black, it could be classified as bio-based; however, its main industrial production route is oil-based.

Fogging occurs on the surface of transparent polymer films through the formation of a layer of water microdroplets. This layer drastically reduces the light transmittance of the film. In packaging and greenhouse coverings, transparency of the films is important and fogging has to be precluded. Antifogging agents act on the film surface and have a
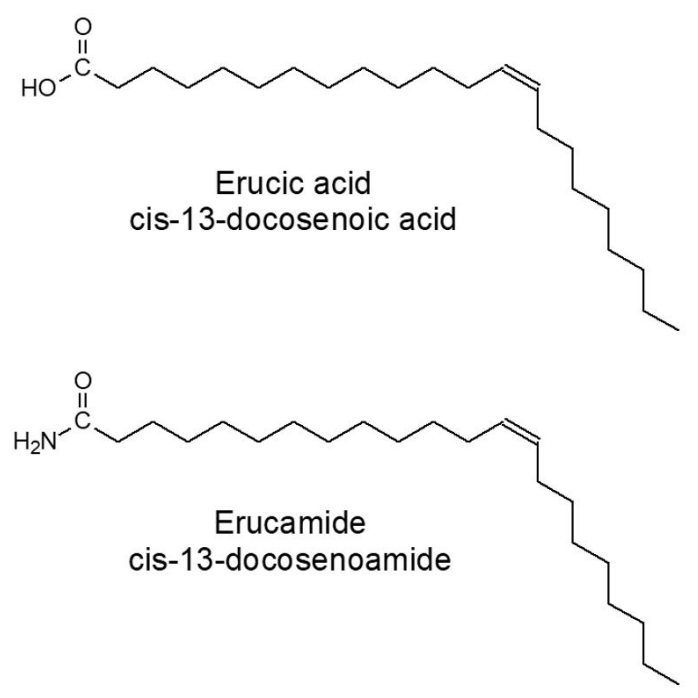

Figure 2. Chemical representations of the raw material Erucic acid (top) and the antistatic agent Erucamide (bottom).

Table 3. Examples of bio-based biocides currently in the market.

\begin{tabular}{|c|c|c|c|c|}
\hline Trade name & Composition & Manufacturer & Comments & Refs. \\
\hline Gaia $^{\circledast}$ AB 504/505 & Derivatives from citrus extracts & Phoenixplastics (USA) & 504: Specified for rotational molding. & {$[29]$} \\
\hline & & & 505: Specified for extrusion and injection & \\
\hline Gaia $^{\circledR}$ Byoprotec & $\begin{array}{l}\text { Citric acid, citrus extracts } \\
\text { and quaternary ammonium } \\
\text { chloride salts }\end{array}$ & Phoenixplastics (USA) & Blown film, injection molding and extrusion. & [29] \\
\hline
\end{tabular}


mechanism of action very similar to antistatic agents. The hydrophilic end of the long hydrocarbon molecule migrates to the surface of the hydrophobic film. This hydrophilic end interacts with the water microdroplets and increases the water contact angle with the film surface, restoring transparency. The above-mentioned bio-based glycerol esters are also used as antifogging agents.

Sorbitan esters are molecules with a hydrophobic chain and a hydrophilic end; they are industrially used as antifogging agents, Figure 3. Sorbitan is produced by the dehydration of sorbitol, which can be obtained from cellulose ${ }^{[31]}$. The dehydration reaction usually produces sorbitan as a mixture of five- and six-membered cyclic ethers (1,4-anhydrosorbitol, 1,5-anhydrosorbitol, and 1,4,3,6-dianhydrosorbitol) and the five-membered 1,4-anhydrosorbitol form is the main product ${ }^{[32]}$. The antifogging agents are sorbitan monostearate and sorbitan monolaurate, which are obtained by the esterification of sorbitol with stearic and lauric acids, respectively. Practically all antifogging agents available on the market are bio-based; however, to the best of our knowledge, there are no oil-based antifogging agents. Table 4 exemplifies bio-based antistatic and antifogging agents, currently in the market.

\subsection{Lubricants}

Lubricants change the rheology of the polymer melt in a desired way. They improve the flow of the polymer melt during processing by extrusion or rotomolding, reducing the effect of shear and the residence time. Besides affecting the rheology, they have other beneficial effects on the properties of the finished articles. They are considered as a processing aid and the reduction of the residence time reduces thermal<smiles>[R]CC(O)C1OCC(O)C1O</smiles>

\section{Sorbitan laurate $\quad \mathrm{R}=\mathrm{OOC}\left(\mathrm{C}_{11} \mathrm{H}_{23}\right)$ Sorbitan stearate $\mathrm{R}=\mathrm{OOC}\left(\mathrm{C}_{17} \mathrm{H}_{35}\right)$ Sorbitan oleate $\quad \mathrm{R}=\mathrm{OOC}\left(\mathrm{C}_{17} \mathrm{H}_{33}\right)$}

Figure 3. Chemical representation of a generic sorbitan ester and three possible substituents used in antifogging additives. and mechanical degradation of the polymer ${ }^{[36]}$. In many cases, the lubricant permits the output of the extrusion process to be maintained by using a lower temperature profile, reducing thermal degradation of the polymer. They can be internal or external, depending on their interaction with the polymer used.

PVC, for example, is not processed without lubricants. For this polymer, polar lubricant molecules act as an internal lubricant, whereas nonpolar molecules are external lubricants. For nonpolar polyolefins, the lubricants have opposite effects.

The bio-based lubricants are waxes derived from fatty acids (stearic and palmitic acids) produced from animal resources, such as beef tallow. Tallow is a rendered form of beef or mutton fat, and is primarily made up of triglycerides. It is solid at room temperature and can be stored for extended periods in an airtight container to prevent oxidation without the need for refrigeration. It is common for commercial tallow to contain fat derived from different animals.

Fats and oils are the raw materials used to produce stearic acid (octadecanoic acid) by the saponification of triglycerides by using hot water $\left(\mathrm{ca} .100^{\circ} \mathrm{C}\right)$. The resulting mixture is distilled to obtain the purified products ${ }^{[22]}$. Commercial stearic acid is often a mixture of stearic and palmitic (hexadecanoic) acids, although purified stearic acid is available. Fats and oils rich in stearic acid are more abundant in animal fat (up to $30 \%$ ) than in vegetable fat (typically $<5 \%$ ). The important exceptions are cocoa and shea butter, where the stearic acid content (as a triglyceride) is $28-45 \% 0^{[37]}$.

The mixture of stearic and palmitic acid, called fatty acids, is directly used as a lubricant in polymer processing by extrusion or calendaring. This mixture is sold under different trade names ${ }^{[38]}$. To comply with market and governmental rules, the source of the fatty acids can be animal or vegetal (for vegano, kosher, or halal food packaging, e.g.) and must be indicated by the producer.

Fatty acid esters of glycerol or ethanol can be also included as bio-based, depending on their source. Glycerol is a byproduct of biodiesel production plants and ethanol is produced from different vegetal species, such as sugar cane or corn. Fatty acid salts, such as sodium and calcium stearates, are also bio-based because they are produced by reacting stearic acid with the corresponding base. These salts are external lubricants for polyolefins and act as acid scavengers for polyolefins and stabilizers for PVC. Table 5 exemplifies bio-based lubricants currently available in the market.

Table 4. Examples of bio-based antistatic and antifogging agents currently in the market.

\begin{tabular}{lllcc}
\hline \multicolumn{1}{c}{ Trade name } & \multicolumn{1}{c}{ Composition } & Manufacturer & Comments & Refs. \\
\hline Rikemal and Rikemaster & Fatty acid esters and organic acid esters of monoglycerides & Riken (Japan) & & ${ }^{[33]}$ \\
Atmer $^{\mathrm{TM}} 129$ & vegetable derived glycerol ester & Croda (UK) & & ${ }^{[34]}$ \\
Atmer $^{\mathrm{TM}} 154$ & Alkoxylated fatty acid ester & Croda (UK) & ${ }^{[34]}$ \\
Atmer $^{\mathrm{TM}} 110 / 116$ & Ethoxylated sorbitan ester & Croda (UK) & Used for PET & ${ }^{[35]}$ \\
\hline
\end{tabular}

Table 5. Examples of bio-based lubricants currently in the market.

\begin{tabular}{llll}
\hline \multicolumn{1}{c}{ Trade name } & \multicolumn{1}{c}{ Composition } & \multicolumn{1}{c}{ Manufacturer } & \multicolumn{1}{c}{ Comments } \\
\hline Atmer $^{\mathrm{TM}} 1013$ & Glycerol ester & Croda (UK) & Applied in expanded polyethylene \\
Crodamide $^{\mathrm{TM}}$ ER & Erucamide & Croda (UK) & Applied in polyolefin films \\
Crodamide $^{\mathrm{TM}}$ EBO & Ethylene-bis-oleamide & Croda (UK) & Applied for wood plastic composites \\
\hline
\end{tabular}




\subsection{Flame-retardants/smoke suppressants}

Historically, one of the first uses for flame-retardants was in the ancient wars, where in the first century BC Roman siege towers were coated with clay reinforced with hair to avoid being burned during the handling or the launching of flaming arrows. Gay-Lussac also participated in the early development of flame retardants with the invention of a fabric for theater curtains, which was treated with a mixture of ammonium phosphate, ammonium chloride, and borax $^{[42]}$. The modern age of flame-retardants started during World War II, with the demand for airplane canvas to be waterproof and resist fire at the same time. In this context, the first halogenated flame retardant was born: chlorinated paraffin, mixed with antimony oxide and a binder ${ }^{[43]}$.

Polymers are a source of concern in our modern daily life because they are a good fuel for fire in the cases of furniture, homes, cars, or airplanes. Presently, the efficient flame-retardants commercially available are hydrated metal hydroxides associated with halogenated compounds. Despite that, environmental concerns about the toxicity of halogenated flame retardants (HFR) are increasing to the point of having a collective statement from 150 scientists against their use, called the San Antonio Statement ${ }^{[44]}$. Together with the environmental concern, the demand for a less toxic alternative drives the research for bio-based flame-retardants.

The mechanism of burning for polymers consists initially of melting and thermal or thermo-oxidative degradation of the melt. Volatiles are formed during degradation and, in contact with heat and oxygen, they start a combustion process, generating the flames and heat for the self-sustenance of the process. This process keeps going until one of the "heat fuel - oxygen" triad is missing. The nature of the polymer can also influence the dynamics of a fire. Thermoplastics can flow and drip during burning, creating a vector for fire spreading, whereas thermosets emit their volatiles directly from the surface while in the solid state, not contributing to fire propagation. Other polymers, like PVC for example, emit toxic gases during burning with hazardous side effects.

The strategy to control or retard the burning of polymers interferes with the heat release or provides a way to decrease the concentration of oxygen in the surroundings of the flame. For this purpose, additives make use of one or more of the strategies below:

1) reduction of the heat released in the gaseous phase and by scavenging reactive radicals;

2) decomposition of thermally released water or carbon dioxide in an endothermic reaction, cooling the system while decreasing the oxygen concentration;

3) use of a char-forming reaction that thermally insulates the substrate, decreasing the propagation of flames in the solid phase under the char and precluding access of oxygen and dispersion of gases to the environment.
One of the concerns regarding flame-retardants currently in use is their toxicity to human health and the environment. Char-forming materials are an alternative and in the scientific literature, there are works with lignin as a char-forming material, which has some additional advantages such as acting as a stabilizer and reinforcing agent ${ }^{[45,46]}$. Despite these properties, there is no commercial product based on lignin using these features. However, there are recent initiatives developed for industry ${ }^{[47]}$, where lignin is covalently bonded to phosphates to avoid phase separation, which limits the flame-retardation effect.

Great Lakes commercializes the product Kronitex ${ }^{\mathrm{TMTCP}}$, which is a triaryl phosphate derived from natural cresol, obtained from coal $\operatorname{tar}^{[48]}$. Despite the criticism around coal production, cresols are considered renewable as they can also be produced from vegetable coal. Another flame-retardant on the market, which are not oil-based and could be considered as being close to the concept of renewability, are nanoclays, such as montmorillonite or bentonite ${ }^{[49]}$. These form a layer of oxides during burning, promote thermal insulation, and form an oxygen diffusion barrier layer.

Some bio-based molecules such as DNA (deoxyribonucleic acid) and phytic acid have been considered for this application, and have achieved good results as flame-retardants ${ }^{[50]}$. This is due to the high concentration of phosphor in these compounds. Despite the significant amount of research using bio-based substances as flame-retardants, highlighted by Dubois and co-workers in a recently published review ${ }^{[36]}$, they are not on the market because they are not yet economically viable ${ }^{[51]}$. Table 6 shows one type of flame-retardant, which can be cited as bio-based, and available in the market.

\subsection{Stabilizers}

Stabilizers are a class of polymer additives comprising primary and secondary antioxidants, photostabilizers, and acid scavengers. Primary antioxidants act as free radical scavengers and secondary antioxidants decompose the hydroperoxide groups formed upon oxidation. Photostabilizers act by different mechanisms, such as UV light absorption, excited state quenchers, filters, or free radical suppression by species generated after UV irradiation. Acid scavengers, or anti-acids, suppress the acid species formed upon decomposition of the polymer (in the case of PVC), acid impurities, or catalyst residues ${ }^{[52]}$.

Primary antioxidants are hindered phenol species with different substituents in the para position of the aromatic ring. The term "hindered phenol" means a 2,6-bis-tert-butyl substituted phenolic ring, Figure 4. A substituent in the para position, in relation to the hydroxylic group, determines the diffusivity of the additive in the polymer matrix. Hindered phenols, such as vitamin E, are also chemical species that act as free radical scavengers, which are used as antioxidants by living organisms ${ }^{[33]}$. Vitamin $\mathrm{E}$ is also a commercial antioxidant for polymer films and for polymeric surgical implants ${ }^{[5,55]}$.

Table 6. Examples of bio-based flame-retardants currently in the market.

\begin{tabular}{clccc}
\hline Trade name & \multicolumn{1}{c}{ Composition } & Manufacturer & Comments & Ref \\
\hline Kronitex ${ }^{\mathrm{TM} T C P}$ & $\begin{array}{l}\text { Naturally derived cresol based tricresyl } \\
\text { phosphate }\end{array}$ & Great Lakes (USA) & $\begin{array}{l}\text { Despite cresols are obtained from naturally occurring } \\
\text { coal tar, they are not considered bio-based. }\end{array}$ & [48] \\
\hline
\end{tabular}


Bio-based phenolic compounds can have, in principle, activity as antioxidants for polymers; however, bio-based materials are a mixture of chemical species. The purification of these mixtures has a strong impact on the final cost and it is more favorable to use them as a mixture. Cashew nut shell oil is a mixture of meta-alkylphenols with variable degrees of unsaturation. Its technical grade shows antioxidant activity towards the thermal degradation of poly(cis-isoprene $)^{[56]}$.

Lignin is the second most abundant polymer on our planet and is a component of vegetal species. It is obtained as a byproduct of cellulose and paper plants and has a high availability at a low price. Lignin has a cross-linked structure containing different hindered phenol structures. Two of these phenols are the 2-methoxy-substituted guaiacyl groups and the 2,6-methoxy-substituted siringyl groups. The chemical structure of lignin, and the siringyl/guaiacyl group ratio, depends on the vegetal species from which it is extracted. The higher this ratio is, the better is its antioxidant activity.

By using this strategy, previous works have demonstrated that lignin extracted from sugar cane bagasse has an antioxidant activity for polybutadiene ${ }^{[57]}$ and styrene-butadiene rubbers $^{[58]}$. The lignin extracted from Eucaliptus grandis, used to produce cellulose by the pulp and paper industry, had its siringyl/guaiacyl ratio determined as 2.1 to $2.5^{[59,60]}$. Formulations containing this lignin showed antioxidant activity for pure polymers and cellulose fiber composites with polypropylene, ${ }^{[61]}$ polyethylene, ${ }^{[62]}$ and polyamide- $6^{[63]}$. In the case of polypropylene, aged formulations containing lignin maintained their properties for a longer period in comparison to formulations aged with a non-bio-based antioxidant ${ }^{[61]}$.
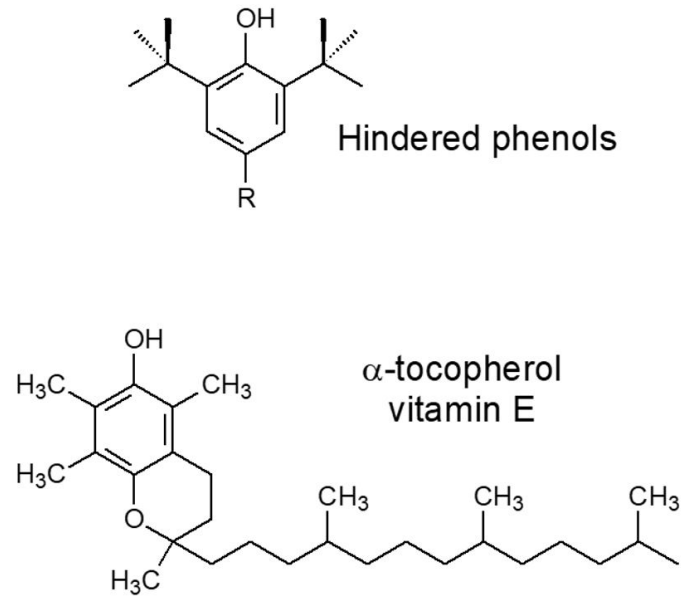

Figure 4. Chemical representations of a hindered phenol (top) and vitamin $\mathrm{E}$ (bottom).
The oil-based antioxidants used for rubber and elastomers are aromatic amines, and the same strategy used with bio-based phenols was applied by Abad et al. ${ }^{[64]}$ to stabilize rubber with amino acids. In this work, cystine, tyrosine, asparagine phenyl alanine, and alanine showed antioxidant activity for vulcanized natural rubber.

The most common secondary antioxidants used for polymers are phosphites, like e.g. tris-nonylphenylphosphite and tris-1,3-di-tert-butylphenylphosphite. To the best of our knowledge, presently there are no bio-based secondary antioxidants on the market; however, they were used in a synergistic association with lignin to stabilize polyethylene ${ }^{[62]}$.

UV absorbers are molecules that form a thermodynamically unstable species by the absorption of UV light, returning in the dark to the initial ground state form. One example is 2-hydroxybenzophenone, which forms an enol when irradiated. The enol form decays to the more thermodynamically stable ketone form, regenerating the stabilizer molecule. This mechanism is known as the keto - enol tautomerization mechanism. This simple mechanism may occur in nature, but no bio-based hydroxybenzophenone products exist on the market. Additive producers suggest the use of stearates as light stabilizers for PVC; however, they really act as acid scavengers, deactivating the $\mathrm{HCl}$ formed upon photodegradation of this polymer. Lignin was reported as a light stabilizer for rubbers, acting as a filter for UV light, similarly to carbon black ${ }^{[43]}$. Another class of commercial photostabilizer are the hindered amines, HALS, which suppress free radicals when irradiated with UV light. In this class, bis(2,2,6,6-tetramethyl-4piperidyl) sebacate (Caplig $770^{\mathrm{TM}}$ ) is a bio-based HALS, produced from sebacic acid, Table 7. Castor oil is the raw material used to produce sebacic acid, by using sodium hydroxide, sulfuric acid, and catalysts including zinc oxide and phenol.

Acid scavengers, or anti-acids, can be ester salts, such as calcium, zinc, or magnesium stearate. Stearic acid is reacted with calcium, zinc, or magnesium hydroxides to produce these salts. The main source of stearic acid is animal fat, where it is present in large concentrations. This origin permits their inclusion as bio-based materials. Use of calcium and zinc stearates as stabilizers, that is, acid suppressors, for PVC and polyolefins is common practice by the industry. Use as a lubricant for polyolefin processing is another application of these salts. On the commercial market, we find the bio-based Struktol ${ }^{\circledR}$ TPW 426, which is a blend of fatty acid derivatives recommended for use with PVC ${ }^{[65]}$.

Table 7. Examples of bio-based stabilizers currently in the market.

\begin{tabular}{|c|c|c|c|c|}
\hline Trade name & Composition & Manufacturer & Comments & Refs. \\
\hline Riken E-Oil Series & Tocoferol derivative & & Used in plastic for food packaging & {$[66]$} \\
\hline Struktol $^{\circledR}$ TPW 426 & Blend of fatty acids derivatives & Struktol (USA) & $\begin{array}{l}\text { Also works as a compatibilizer } \\
\text { in composites }\end{array}$ & [65] \\
\hline Caplig $770^{\mathrm{TM}}$ & Plant based sebacate & $\begin{array}{l}\text { Nanjing Capatue Chemical Co } \\
\text { (China) }\end{array}$ & Similar to HALS & [67] \\
\hline
\end{tabular}




\subsection{Reinforcing agents}

These additives tailor the mechanical properties of thermoplastic polymers, making them fit a specific application with controlled tensile and/or flexural properties. These reinforced materials are called "composites" because they consist of two heterogeneous phases: the polymer and the solid particles of the reinforcing agent. Presently, the most commonly used reinforcing agents are talc and short glass fibers. The predicted market shares are US\$ 3.29 billion dollars for talc in 2021 and US\$ 2.7 billion dollars for glass fibers in $2022^{[68]}$. These reinforcing agents produce excellent mechanical and thermal properties; however, they have a high density and are abrasive to the processing equipment ${ }^{[69]}$. Additionally, mechanical recycling of these composites is energy consuming and not cost effective for industrial purposes ${ }^{[70]}$.

Substitution of the above-mentioned additives for vegetal fibers is common and depends on the development of the adequate processing method, which is frequently through extrusion with a twin-screw extruder. Their main advantage is the lower density, which reduces the weight of the final product; however, vegetal fibers thermally decompose at ca. $200{ }^{\circ} \mathrm{C}$ and most thermoplastics are processed above this temperature. In addition, the high shear ratio in a twin-screw extruder reduces the aspect ratio of vegetal fibers. Thus, the development of an adequate processing method is not trivial. An additional advantage of vegetal fibers is their lower abrasivity to the processing equipment ${ }^{[53]}$.

The challenges in using vegetal fibers are the low thermal degradation temperature, availability, cost, and properties reproducibility. Due to the hydrophilic characteristics of vegetal fibers, in contrast to the hydrophobicity of polyolefins, a compatibilizing agent is also necessary. Despite these challenges, there is a plethora of patents and publications reporting the use of vegetal fibers as reinforcing agents for thermoplastics. The most commonly cited fibers are cellulose, silk, hemp, pineapple leaf, sisal, and curaua (the last three are bromeliaceae with long leaves ${ }^{[71]}$. The choice depends on the regional availability and cost.

Among these vegetal fibers, curaua fibers have mechanical properties similar to glass fibers. Their composites with polypropylene $\mathrm{e}^{[72]}$, high-density polyethylene ${ }^{[73]}$, and polyamide- $6^{[74]}$ can substitute their glass fiber counterparts in several applications. It was used by the automotive industry in the past but, unfortunately, the production of curaua fibers is limited and their price is not competitive in relation to glass fibers.
Hemp fibers have been extensively used throughout history. For centuries, ropes, sails, and textiles were made with hemp fibers. Presently, some car industries use hemp for composites with thermosets; however, textiles are the main market application for these fibers.

India and Brazil produce sisal fibers on a large scale for many different applications. Sisal fiber is a lignocellulosic material produced with reproducible properties. The long fibers extracted from the leaves (1.0 to $1.5 \mathrm{~m}$ long) of the sisal plant are milled and dried before being fed into the extruder to disperse in the thermoplastic. Their low density precludes the use of gravimetric dosimeters and other feeding techniques are used. Composites of polypropylene or high-density polyethylene with $30 \mathrm{wt}$ \% of sisal fibers have tensile and flexural properties comparable to those using glass fibers ${ }^{[75]}$. Presently, other markets are more financially attractive for sisal fibers in comparison to polymer reinforcement.

Cellulose is the most abundant polymer in the world; it is present in all vegetal species. The mechanical properties and degree of crystallinity of the cellulose fibers depend on the vegetal species from which they are extracted ${ }^{[76]}$. The pulp and paper industries choose selected species of wood to produce cellulose fibers on a large scale with reproducible properties. In terms of availability and cost, cellulose fibers are the most favorable bio-based fibers to use in reinforced composites of thermoplastics. Oksman and co-workers published a series of reports on the preparation of polypropylene composites reinforced with cellulose fibers by using a twin-screw extruder ${ }^{[77,78]}$. Their low density is an advantage, but difficulties in feeding the extruder were also encountered. Pelletizing the cellulose fibers was the solution employed to avoid this ${ }^{[79]}$. Our group developed composites of cellulose fibers with high-density polyethylene $(\text { HDPE })^{[48]}$ and polyamide- $6^{[49]}$. For HDPE, a maleated polyethylene was used as compatibilizer. For polypropylene, the association of the cellulose fibers with lignin improved the stability and mechanical properties in comparison to using bleached cellulose fibers ${ }^{[80]}$. As long as paper is the main market for the cellulose and pulp industries, there will be low investment in using it for thermoplastic composites. The same applies to nanocellulose; however, we cite one commercial product in Table 8 .

In the future, we predict that this trend will revert and bio-based reinforcing agents will gradually substitute glass fiber and talc for most applications. Additionally, they will facilitate the thermal recycling of thermoplastic composites for energy production.

Table 8. Examples of bio-based reinforcing agents currently in the market.

\begin{tabular}{|c|c|c|c|c|}
\hline Trade name & Composition & Manufacturer & Comments & Refs. \\
\hline DuraSense $^{\mathrm{TM}}$ & Wood fiber composites & Stora Enso (Finland/Sweden) & $\begin{array}{l}\text { The DuraSense family ranges } \\
\text { the proportion of wood fibers } \\
(30-60 \%) \text { and the nature of the } \\
\text { polymers (fossil- or bio-based) }\end{array}$ & [81] \\
\hline $\mathrm{NeCycle}^{\mathrm{TM}}$ & Cellulose resin bonded with cardanol & NEC (Japan) & & [82] \\
\hline powerRibs $^{\mathrm{TM}}$ & $\begin{array}{l}\text { Natural fiber composite } \\
\text { reinforcement grid }\end{array}$ & Bcomp (Switzerland) & $\begin{array}{l}\text { Can be used both in thermoplastics } \\
\text { or thermosets }\end{array}$ & [83] \\
\hline $\mathrm{UBQ}^{\mathrm{TM}}$ & bio-based thermoplastic composite & UBQ (Israel) & $\begin{array}{l}\text { The biomass is extracted mainly } \\
\text { from unsorted municipal solid waste }\end{array}$ & [84] \\
\hline Nano Cellulose & Cellulose nanofibers & Green Science Alliance (Japan) & & {$[85,86]$} \\
\hline
\end{tabular}




\section{Conclusions}

In this review, we focused on bio-based additives that are produced and marketed, or have the potential, for use by industry. We note that there is a global tendency to substitute oil-based for bio-based raw materials and, as seen above, the polymer additives industry is following this trend, aiming to reduce environmental impact with no changes in performance and no impact on the final cost of their products. This trend will certainly benefit the environment and customers. There is a large number of publications focusing on the characterization and use of bio-based additives; however, a limited number of these products are produced (even in pilot plant scale), or have reached the market. The limitations on marketability are mainly due to cost and availability.

As a final remark, it is common knowledge of the researchers on bio-based additives for thermoplastics to focus mainly on the relationships between composition and final properties of the materials. While we consider that basic science is of paramount importance for technological development, it is striking that the vast majority of the works that seek technological solutions do not present their results along with a cost analysis and/or considerations regarding logistics. We believe that much of this gap comes from the lack of familiarity with the fundamental practices for patenting and licensing of a process or product to the productive sector. As a final suggestion, we recommend, as a way to fill this gap, the development of partnerships with the productive sector, both in the additives industry and in the agricultural sector, for the development of economically and logistically feasible solutions.

\section{Acknowledgements}

MAP acknowledges a Senior Researcher fellowship from CNPq and WRW the São Paulo Research Foundation (FAPESP) for the grant 2016/24936-3.

\section{References}

1. Vert, M., Doi, Y., Hellwich, K.-H., Hess, M., Hodge, P., Kubisa, P., Rinaudo, M., \& Schué, F. (2012). Terminology for biorelated polymers and applications (IUPAC Recommendations). Pure and Applied Chemistry, 84(2), 377-410. http://dx.doi. orgb/10.1351/PAC-REC-10-12-04.

2. Markets and Markets. (2017). Retrieved in 2017, November 30, from https://www.marketsandmarkets.com/PressReleases/ plasticizers.asp

3. Zion Market Research. (2019). Retrieved in 2019, February 19, from https://www.zionmarketresearch.com/news/bioplasticizers-market

4. Holser, R. A. (2008). Transesterification of epoxidized soybean oil to prepare epoxy methyl esters. Industrial Crops and Products, 27(1), 130-132. http://dx.doi.org/10.1016/j. indcrop.2007.06.001.

5. Sienel, G., Rieth, R., \& Rowbottom, K. T. (2005). Epoxides. In F. Ullmann. Ullmann's encyclopedia of industrial chemistry. Weinheim: Wiley-VCH. http://dx.doi.org/10.1002/14356007. a09_5311.

6. Bueno-Ferrer, C., Garrigós, M. C., \& Jiménez, A. (2010). Characterization and thermal stability of poly(vinylchloride) plasticized with epoxidized soybean oil for food packaging.
Polymer Degradation \& Stability, 95(11), 2207-2212. http:// dx.doi.org/10.1016/j.polymdegradstab.2010.01.027.

7. Bouchoul, B., Benaniba, M.T., \& Massardier, V. (2017). Thermal and mechanical properties of bio-based plasticizers mixtures on poly(vinyl chloride). Polímeros: Ciência e Tecnologia, 27(3), 237-246. http://dx.doi.org/10.1590/0104-1428.14216.

8. SpecialChem. (2017). Retrieved in 2017, November 30, from https://polymer-additives.specialchem.com/searchsites/searc hproducts?q=bioplasticizers

9. Future Market Insights. (2017). Bio-plasticizers market: global industry analysis and opportunity assessment 20152025. Retrieved in 2017, November 30, from https://www. futuremarketinsights.com/reports/bio-plasticizers-market

10. Hallstar. (2019). Plasthall. Retrieved in 2019, February 20, from https://www.hallstar.com/brand/plasthall/

11. Arkema. (2019). Vikoflex ${ }^{\circledR}$ epoxidized vegetable oils. Retrieved in 2019, February 1, from https://www.arkema.com/en/products/ product-finder/range-viewer/Vikoflex-epoxidized-vegetableoils/2/

12. ExxonMobil. (2019). Adipate plasticizers. Retrieved in 2019, January 28, from https://www.exxonmobilchemical.com/en/ products/plasticizers/adipate-plasticizers

13. Vertellus. (2019). Dibutyl sebacate. Retrieved in 2019, January 28, from https://www.vertellus.com/products/plastics-polymers/ morflex-plasticizers-sebacates-and-solvents/dibutyl-sebacate

14. PolyOne. (2019). Reflex ${ }^{\mathrm{TM}}$ bio-derived plasticizer. Retrieved in 2019, January 28, from http://www.polyone.com/products/ plasticizers-synthetic-esters/reflex-bio-derived-plasticizers

15. Woodward, J. (1724). IV. Præparatio cærulei prussiaci ex germaniâ missa ad Johannem Woodward, M. D. Prof. Med. Gresh. R. S. S. Philosophical Transactions of the Royal Society of London, 33(381), 15-17. http://dx.doi.org/10.1098/ rstl.1724.0005.

16. Böhland, T., Brandt, K., Brussaard, H., Calvert, D., Etzrodt, G., Rieck, H., Seeger, O., Wienand, H., Wiese, J., \& Buxbaum, G. (2005). Colored pigments. In G. Buxbaum \& G. Pfaff (Eds.), Industrial inorganic pigments (pp. 99-162). Weinheim: Wiley-VCH. http://dx.doi.org/10.1002/3527603735.ch3.

17. Farrugia, V. M., Birau, M. M., Iftime, G., \& Abraham, B. E. (2015). US Patent No. 9181389B2. Norwalk: Xerox Corporation. Retrieved in 2017, November 30, from https://patentimages. storage.googleapis.com/48/f4/01/21b5ae9d87eae3/US9181389. pdf

18. Yusuf, M., Shabbir, M., \& Mohammad, F. (2017). Natural colorants: historical, processing and sustainable prospects. Natural Products and Bioprospecting, 7(1), 123-145. http:// dx.doi.org/10.1007/s13659-017-0119-9. PMid:28093670.

19. van den Oever, M. J. A., Boeriu, C. G., Blaauw, R., \& van Haveren, J. (2004). Colorants based on renewable resources and food-grade colorants for application in thermoplastics. Journal of Applied Polymer Science, 92(5), 2961-2969. http:// dx.doi.org/10.1002/app.20298.

20. PolyOne. (2019). Oncolor ${ }^{\mathrm{TM}}$ bio colorants. Retrieved in 2019, January 29, from http://www.polyone.com/products/polymercolorants/solid-color-masterbatches/oncolor-bio

21. Burt, S. A., Ojo-Fakunle, V. T. A., Woertman, J., \& Veldhuizen, E. J. A. (2014). The natural antimicrobial carvacrol inhibits quorum sensing in chromobacterium violaceum and reduces bacterial biofilm formation at sub-lethal concentrations. PLoS One, 9(4), e93414. http://dx.doi.org/10.1371/journal. pone.0093414. PMid:24691035.

22. Atarés, L., \& Chiralt, A. (2016). Essential oils as additives in biodegradable films and coatings for active food packaging. Trends in Food Science \& Technology, 48, 51-62. http://dx.doi. org/10.1016/j.tifs.2015.12.001. 
23. Raafat, D., \& Sahl, H.-G. (2009). Chitosan and its antimicrobial potential - a critical literature survey. Microbial Biotechnology, 2(2), 186-201. http://dx.doi.org/10.1111/j.1751-7915.2008.00080.x. PMid:21261913.

24. Raafat, D., von Bargen, K., Haas, A., \& Sahl, H. G. (2008). Insights into the mode of action of Chitosan as an antibacterial compound. Applied and Environmental Microbiology, 74(12), 3764-3773. http://dx.doi.org/10.1128/AEM.00453-08. PMid: 18456858.

25. Goy, R. C., Britto, D., \& Assis, O. B. G. (2009). A review of the antimicrobial activity of chitosan. Polimeros: Ciência e Tecnologia, 19(3), 241-247. http://dx.doi.org/10.1590/S010414282009000300013.

26. van den Broek, L. A. M., Knoop, J. I. R., Kappen, F. H. J., \& Boeriu, C. G. (2015). Chitosan films and blends for packaging material. Carbohydrate Polymers, 116(2), 237-242. http:// dx.doi.org/10.1016/j.carbpol.2014.07.039. PMid:25458295.

27. Biron, M. (2012). What's the latest in biocides?. Paris: SpecialChem. Retrieved in 2017, November 30, from https:// polymer-additives.specialchem.com/tech-library/article/ what-s-the-latest-in-biocides? src=pbsc-4B5267B9-2377467F-8A9D-9E54C9C26A81-pushbottom-3\#P5

28. Kmiotek, M., Bielinski, D., \& Piotrowska, M. (2018). Propolis as an antidegradant and biocidal agent for natural rubber. Journal of Applied Polymer Science, 135(9), 45911. http:// dx.doi.org/10.1002/app.45911.

29. Phoenix Plastics. (2019). The plastic additives experts. Retrieved in 2019, February 19, from http://phoenixplastics.com/products/ antimicrobial

30. Anneken, D. J., Both, S., Christoph, R., Fieg, G., Steinberner, U., \& Westfechtel, A. (2006). Fatty acids. In F. Ullmann. Ullmann's Encyclopedia of Industrial Chemistry. Weinheim: Wiley-VCH. http://dx.doi.org/10.1002/14356007.a10_245. pub21.

31. Kobayashi, H., \& Fukuoka, A. (2013). Synthesis and utilization of sugar compounds derived from lignocellulosic biomass. Green Chemistry, 15(7), 1740-1763. http://dx.doi.org/10.1039/ c3gc00060e.

32. Yamaguchi, A., Hiyoshi, N., Sato, O., \& Shirai, M. (2011). Sorbitol dehydration in high temperature liquid water. Green Chemistry, 13(4), 873-881. http://dx.doi.org/10.1039/c0gc00426j.

33. Riken. (2019). Improving agents for plastics. Retrieved in 2019, January 29, from https://www.rikenvitamin.com/chemicals/ plastics.html

34. Croda. (2019). Additives for automotive plastics. Retrieved in 2019, February 7, from https://www.crodapolymeradditives. com/en-gb/products-and-applications/automotive-plastics\#tabcollapse-anti-static

35. Croda. (2019). PET. Retrieved in 2019, January 29, from https://www.crodapolymeradditives.com/en-gb/products-andapplications/pet

36. Richter, E. (2001). Lubricants. In H. Zweifel (Ed.), Plastics additives handbook (pp. 511-552). Munich: Hanser Publishers.

37. Beare-Rogers, J., Dieffenbacher, A., \& Holm, J. V. (2001). Lexicon of lipid nutrition (IUPAC Technical Report). Pure and Applied Chemistry, 73(4), 685-744. http://dx.doi.org/10.1351/ pac200173040685.

38. SpecialChem. (2018). Universal Selector. Retrieved in 2018, May 22, from https://polymer-additives.specialchem.com/ selectors/bb-true/c-additives-lubricants-waxes-fatty-acids

39. Croda. (2019). Expanded polyethylene. Retrieved in 2019, February 1, from https://www.crodapolymeradditives.com/ en-gb/products-and-applications/expanded-polyethylene\#tabcollapse-processing-aid
40. Croda. (2019). Film production. Retrieved in 2019, February 1, from https://www.crodapolymeradditives.com/en-gb/ products-and-applications/film-production\#tab-collapse-slip

41. Croda. (2019). Wood plastic composites. Retrieved in 2019, February 1, from https://www.crodapolymeradditives.com/ en-gb/products-and-applications/wood-plastic-composites\#tabcollapse-lubrication

42. Gay-Lussac, J. L. (1821). Note sur la propriete qu'ont les matieres salines de rendre les tissus incombustibles. In Annales de Chimie et de Physique (p. 211-216). Paris: De L'Imprimerie de Feugueray. Retrieved in 2018, May 22, from https://gallica. bnf.fr/ark:/12148/bpt6k65709933.image

43. Hindersinn, R. R. (1990). Historical aspects of polymer fire retardance. In L. N. Gordon (Ed.), Fire and polymers (pp. $87-$ 96). Washington: American Chemical Society. http://dx.doi. org/10.1021/bk-1990-0425.ch007.

44. DiGangi, J., Blum, A., Bergman, A., de Wit, C. A., Lucas, D., Mortimer, D., Schecter, A., Scheringer, M., Shaw, S. D., \& Webster, T. F. (2010). San Antonio statement on brominated and chlorinated flame retardants. Environmental Health Perspectives, 118(12), A516-A518. http://dx.doi.org/10.1289/ ehp.1003089. PMid:21123135.

45. Liu, L., Qian, M., Song, P., Huang, G., Yu, Y., \& Fu, S. (2016). Fabrication of green lignin-based flame retardants for enhancing the thermal and fire retardancy properties of polypropylene/wood composites. ACS Sustainable Chemistry \& Engineering, 4(4), 2422-2431. http://dx.doi.org/10.1021/ acssuschemeng.6b00112.

46. Mandlekar, N., Cayla, A., Rault, F., Giraud, S., Salaün, F., Malucelli, G., \& Guan, J. (2017). Thermal stability and fire retardant properties of polyamide 11 microcomposites containing different lignins. Industrial \& Engineering Chemistry Research, 56(46), 13704-13714. http://dx.doi.org/10.1021/acs. iecr.7b03085.

47. Edser, C. (2017). Fraunhofer LBF develops lignin-based flame retardant from paper manufacturing waste (Business News). Additives for Polymers, 2017(12), 1-2. http://dx.doi. org/10.1016/S0306-3747(18)30001-0.1

48. Great Lakes Solutions. (2019). Flame retardants product guide. Retrieved in 2019, February 21, from http://greatlakes.com/ deployedfiles/ChemturaV8/GreatLakes/Flame\%20Retardants/ FR\%20Brochures/Flame\%20Retardants\%20Product\%20Guide. pdf

49. Oliveira, S. V., Araújo, E. M., Pereira, C. M. C. \& Leite, A. M. D. (2017). Nanocompósitos de polietileno/argila bentonítica com propriedades antichama. Polímeros: Ciência e Tecnologia, 27(n.spe), 91-98. http://dx.doi.org/10.1590/0104-1428.2288.

50. Costes, L., Laoutid, F., Brohez, S., \& Dubois, P. (2017). Biobased flame retardants: when nature meets fire protection. Materials Science and Engineering R Reports, 117(7), 1-25. http://dx.doi.org/10.1016/j.mser.2017.04.001.

51. Chemistry World. (2018). Fireproof coatings made from DNA. Retrieved in 2018, May 30, from https://www.chemistryworld. com/research/fireproof-coatings-made-from-dna/5941.article

52. De Paoli, M. A. (2009). Degradação e estabilização de polímeros. São Paulo: Artliber.

53. Yamauchi, R. (1997). Vitamin E: mechanism of its antioxidant activity. Food Science and Technology International Tokyo, 3(4), 301-309. http://dx.doi.org/10.3136/fsti9596t9798.3.301.

54. Strandberg, C., \& Albertsson, A.-C. (2005). Process efficiency and long-term performance of $\alpha$-tocopherol in film-blown linear low-density polyethylene. Journal of Applied Polymer Science, 98(6), 2427-2439. http://dx.doi.org/10.1002/app.22435.

55. Renò, F., Bracco, P., Lombardi, F., Boccafoschi, F., Costa, L., \& Cannas, M. (2004). The induction of MMP-9 release from granulocytes by vitamin E in UHMWPE. Biomaterials, 25(6), 
995-1001. http://dx.doi.org/10.1016/S0142-9612(03)00623-9. PMid:14615164.

56. Rodrigues, F. H. A., Feitosa, J. P. A., Ricardo, N. M. P. S., França, F. C. F., \& Carioca, J. O. B. (2006). Antioxidant activity of cashew nut shell liquid (CNSL) derivatives on the thermal oxidation of synthetic cis-1,4-polyisoprene. Journal of the Brazilian Chemical Society, 17(2), 265-271. http://dx.doi. org/10.1590/S0103-50532006000200008.

57. De Paoli, M. A., \& Furlan, L. T. (1985). Sugar cane bagasse-lignin as photostabilizer for butadiene rubber. Polymer Degradation \& Stability, 11(4), 327-337. http://dx.doi.org/10.1016/01413910(85)90036-9.

58. De Paoli, M. A., Rodrigues, M. A., \& Furlan, L. T. (1985). Sugar cane bagasse-lignin as stabilizer for rubbers III: Styrenebutadiene rubber and natural rubber. Polymer Degradation \& Stability, 13(4), 337-350. http://dx.doi.org/10.1016/01413910(85)90082-5.

59. Barbosa, C. A., Maltha, C. R. A., Silva, V. L., \& Colodette, J. L. (2008). Determinação da relação siringila/guaiacila da lignina em madeiras de eucalipto por pirólise acoplada à cromatografia gasosa e espectrometria de massas (pi-cg/em). Quimica Nova, 31(8), 2035-2041. http://dx.doi.org/10.1590/ S0100-40422008000800023.

60. Nunes, C. A., Lima, C. F., Barbosa, L. C. A., Colodette, J. L., Gouveia, A. F. G., \& Silverio, F. O. (2010). Determination of Eucalyptus spp lignin S/G ratio: a comparison between methods. Bioresource Technology, 101(11), 4056-4061. http:// dx.doi.org/10.1016/j.biortech.2010.01.012. PMid:20133130.

61. Gadioli, R., Waldman, W. R., \& De Paoli, M. A. (2016). Lignin as a green primary antioxidant for polypropylene. Journal of Applied Polymer Science, 133(45). http://dx.doi.org/10.1002/ app.43558.

62. Guilhen, A., Gadioli, R., Fernandes, F. C., Waldman, W. R., \& De Paoli, M. A. (2017). High-density green polyethylene biocomposite reinforced with cellulose fibers and using lignin as antioxidant. Journal of Applied Polymer Science, 134(35), 45219. http://dx.doi.org/10.1002/app.45219.

63. Fernandes, F. C., Gadioli, R., Yassitepe, E., \& De Paoli, M. A. (2017). Polyamide- 6 composites reinforced with cellulose fibers and fabricated by extrusion: effect of fiber bleaching on mechanical properties and stability. Polymer Composites, 38(2), 299-308. http://dx.doi.org/10.1002/pc.23587.

64. Abad, L. V., Relleve, L. S., Aranilla, C. T., Aliganga, A. K., San Diego, C. M., \& dela Rosa, A. M. (2002). Natural antioxidants for radiation vulcanization of natural rubber latex. Polymer Degradation \& Stability, 76(2), 275-279. http:// dx.doi.org/10.1016/S0141-3910(02)00024-1.

65. Struktol TPW426 Technical Data. (2019). Retrieved in 2019, February 20, from http://www.struktol.com/pdfs/TD $\% 20$ TPW426.pdf

66. Riken. (2019). Improving agents for plastics. Retrieved in 2019 , January 29, from https://www.rikenvitamin.com/chemicals/ plastics.html

67. SpecialChem. (2019). Caplig 770. Retrieved in 2019, February, from https://polymer-additives.specialchem.com/product/ananjing-capatue-chemical-caplig-770

68. Industry Experts. (2017). Glass fiber reinforcements - a global market overview. Retrieved in 2019, May 5, from http:// industry-experts.com/verticals/chemicals-and-materials/ glass-fiber-reinforcements-a-global-market-overview

69. Franco, M. F., Gadioli, R., \& De Paoli, M. A. (2019). Presence of iron in polymers extruded with corrosive contaminants or abrasive fillers. Polímeros: Ciencia e Tecnologia, 29(2), e2019021.

70. Oliveux, G., Dandy, L. O., \& Leeke, G. A. (2015). Current status of recycling of fibre reinforced polymers: Review of technologies, reuse and resulting properties. Progress in Materials Science, 72(7), 61-99. http://dx.doi.org/10.1016/j. pmatsci.2015.01.004.

71. Pereira, P. H. F., Rosa, M. F., Cioffi, M. O., Benini, K. C. C. C., Milanese, A. C., Voorwald, H. J. C., \& Mulinari, D. R. (2015). Vegetal fibers in polymeric composites: a review. Polímeros Ciência e Tecnologia, 25(1), 9-22. http://dx.doi. org/10.1590/0104-1428.1722.

72. Mano, B., Araujo, J. R., Waldman, W. R., Spinacé, M. A. S., \& De Paoli, M. A. (2013). Mechanical properties, morphology and thermal degradation of a biocomposite of polypropylene and curaua fibers: coupling agent effect. Polimeros Ciência e Tecnologia, 23(2), 161-168. http://dx.doi.org/10.1590/S010414282013005000025 .

73. Araujo, J. R., Mano, B., Teixeira, G. M., Spinacé, M. A. S., \& De Paoli, M. A. (2010). Biomicrofibrilar composites of high density polyethylene reinforced with curaua fibers: mechanical, interfacial and morphological properties. Composites Science and Technology, 70(11), 1637-1644. http://dx.doi.org/10.1016/j. compscitech.2010.06.006.

74. Santos, P. A., Spinacé, M. A. S., Fermoselli, K. K. G., \& De Paoli, M. A. (2007). Polyamide-6/vegetal fiber composite prepared by extrusion and injection molding. Composites. Part A, Applied Science and Manufacturing, 38(12), 2404-2411. http://dx.doi.org/10.1016/j.compositesa.2007.08.011.

75. Spinacé, M. A. S., Janeiro, L. G., Bernardino, F. C., Grossi, T. A., \& Paoli, M.-A. D. (2011). Poliolefinas reforçadas com fibras vegetais curtas: sisal x curauá. Polímeros: Ciência e Tecnologia, 21(3), 168-174. http://dx.doi.org/10.1590/S010414282011005000036.

76. John, M. J., \& Thomas, S. (2008). Biofibres and biocomposites. Carbohydrate Polymers, 71(3), 343-364. http://dx.doi. org/10.1016/j.carbpol.2007.05.040.

77. Bengtsson, M., Le Baillif, M., \& Oksman, K. (2007). Extrusion and mechanical properties of highly filled cellulose fibre-polypropylene composites. Composites. Part A, Applied Science and Manufacturing, 38(8), 1922-1931. http://dx.doi. org/10.1016/j.compositesa.2007.03.004.

78. Le Baillif, M., \& Oksman, K. (2009). The effect of processing on fiber dispersion, fiber length, and thermal degradation of bleached sulfite cellulose fiber polypropylene composites. Journal of Thermoplastic Composite Materials, 22(2), 115133. http://dx.doi.org/10.1177/0892705708091608.

79. Le Baillif, M., \& Echtermeyer, A. (2010). Effect of the preparation of cellulose pellets on the dispersion of cellulose fibers into polypropylene matrix during extrusion. Journal of Applied Polymer Science, 115(5), 2794-2805. http://dx.doi. org/10.1002/app.30421.

80. Gadioli, R., Morais, J. A., Waldman, W. R., \& De Paoli, M. A. (2014). The role of lignin in polypropylene composites with semi-bleached cellulose fibers: mechanical properties and its activity as antioxidant. Polymer Degradation \& Stability, 108(6), 23-34. http://dx.doi.org/10.1016/j.polymdegradstab.2014.06.005.

81. Stora Enso. (2019). DuraSenseTM prodct family. Retrieved in 2019, February 11, from https://www.storaenso.com/en/ products/biocomposites/durasense-product-family

82. NEC Corporation. (2019). Using bioplastics in products. Retrieved in 2019, February 11, from https://www.nec.com/ en/global/eco/product/bioplastic/index.html

83. Bcomp. (2019). PowerRibsTM. Retrieved in 2019, February 11, from http://www.bcomp.ch/en/products/powerribs

84. UBQ. (2019). Sustainable materials for a circular economy. Retrieved in 2019, February 11, from https://ubqmaterials. com/materials/ 
85. Green Science Alliance. (2019). Reseach \& products list. Retrieved in 2019, February 11, from https://www.gsalliance. co.jp/en/product/page/2/1

86. Francis, S. (Ed.). (2019). Green Science Alliance Co. Ltd. manufactures new nano cellulose composites. Composites World. Retrieved in 2019, February 11, from https://www. compositesworld.com/news/green-science-alliance-co-ltdmanufactures-new-nano-cellulose-composites

Received: Oct. 02, 2018 Revised: Feb. 28, 2019 Accepted: Mar. 01, 2019 